\title{
Penerapan Model Blended Learning Dengan Media Hologram 3D Sebagai Inovasi Pembelajaran Fisika Untuk Meningkatkan Kemampuan Kognitif Siswa SMA di Abad 21
}

\author{
Anggiani $^{1}$, Nana ${ }^{2}$ \\ ${ }^{1}$ Mahasiswa Program Studi Pendidikan Fisika, Universitas Siliwangi \\ ${ }^{2}$ Dosen Program Studi Pendidikan Fisika, Universitas Siliwangi \\ Email:29anggiani@gmail.com
}

\begin{abstract}
D holographic media as physics learning innovations to improve the cognitive abilities of high school students in the 21st century. This research is motivated by technological developments in the field of education in the 21 st century which is increasingly advanced. Therefore, 3D hologram media is needed as an alternative to improve students cognitive abilities in the 21st century. In learning physics, appropiate technology is needed to make it easier for teachers to deliver material to students. The method used in this research in the study of literature by studying some literature to be analyzed and made conclusions.
\end{abstract}

Key words: Blended Learning, 3D Hologram, Cognitive abilities

Abstrak - Penelitian ini bertujuan untuk mendeskripsikan penerapan model blended learning dengan media hologram 3D sebagai inovasi pembelajaran fisika untuk meningkatkan kemampuan kognitif siswa SMA di abad 21. Penelitian ini dilatar belakangi oleh pekembangan teknologi di bidang pendidikan pada abad 21 yang semakin maju. Oleh karena itu dibutuhkan media hologram 3D sebagai alternatif untuk menigkatkan kemampuan kogntif siswa di abad 21. Dalam pembelajaran fisika dibutuhkan teknologi yang tepat untuk memudahkan guru menyampaikan materi kepada siswa. Metode yang digunakan dalam penelitan ini yaitu dengan studi kepustakaan dengan mengkaji beberapa literatur untuk dianalisis dan dibuat kesimpulan.

Kata kunci: Blended Learning, Hologram 3D, Kemampuan Kognitif

\section{PENDAHULUAN}

Perkembangan Ilmu Pengetahuan dan Teknologi (IPTEK) pada abad 21 berkembang sangat pesat. Perkembangan ini memiliki dampak semakin terbuka dan tersebarnya informasi dan pengetahuan dari dan ke seluruh dunia menembus batas jarak, tempat, ruang dan waktu (Nana \& Surahman, 2019). Menurut Frydenberg \& Andone (Akhmalia dkk., 2018) hal ini menyebabkan terjadinya perubahan dalam dunia pendidikan, dalam menghadapi perubahan tersebut peserta didik dituntut untuk memiliki keterampilan berpikir yang kritis, pengetahuan dan kemampuan literasi digital, literasi informasi, dan literasi media serta menguasai teknologi informasi dan komunikasi. Di era perkembangan teknologi yang pesat ini, timbul permasalahanpermasalahan di dunia pendidikan. Menurut Pramuda \& Angraeni (2016: 158) fisika sebagai salah satu ilmu pengetahuan dalam rumpun sains yang berkaitan langsung dengan aplikasinya di bidang teknologi, bila dikuasai dengan baik dapat mempersiapkan mahasiswa untuk 'melek teknologi' guna memahami diri dan lingkungan sekitarnya melalui pengembangan keterampilan proses, sikap ilmiah, penguasaan konsep sains yang esensial, serta kreativitas dengan kegiatan 
berbasis teknologi. Oleh karena itu, agar proses pemberajaran pada abad 21 sukses guru harus merancang model pembelajaran yang mampu mamuat keterampilan pada abad 21. Hal yang dapat dilakukan yaitu dengan menerapkan penggunaan internet dalam proses pembelajaran. Penggunaan internet dalam proses pembelajaran mampu mengembangkan kemampuan kognitif siswa dalam keterampilan teknologi dan media informasi. Salah satu upaya untuk meningkatkan keterampilan teknologi di bidang pendidikan yaitu dengan metode blended learning dalam proses pembelajaran. Blended learning menurut Rovai \& Jordan (2004: 3) adalah gabungan keunggulan pembelajaran dimana dilakukan secara tatap muka (face-to-face learning) dan secara virtual (e-learning). Menurut Rahmasari \& Rismiati (Nana \& Surahman, 2019) ELearning merupakan suatu istilah yang dapat kita temukan dalam dunia komputer atau internet. Kata e-learnig terdiri atas 2 (dua) bagian yaitu "e" yang berarti "elektronik" dan "learning" yang berarti "pembelajaran". Jadi kata e-learning dapat diartikan sebagai suatu sistem pembelajaran yang menggunakan perangkat elektronik sebagai media pembelajarannya. E-learning merupakan salah satu metode baru dalam proses pembelajaran dimana banyak sekali kegunaanya diantaranya: a) memudahkan komunikasi antara guru dan murid; b) menambah motivasi belajar anak; c) mendapatkan informasi dengan mudah melalui internet; d) terbentuknya komunitas belajar secara online memalui aplikasi seperti line, whatsapp, google classroom, dll.

Dalam proses pembelajaran dengan menggunakan model blended learning dibutuhkan media yang tepat sehingga model tersebut dapat berjaran dengan baik dalam proses pembelajaran. Hologram merupakan salah satu media yang efektif untuk proses pembelajaran menggunakan model blended learning. Dalam hal ini penggunaan media hologram 3D pada metode blended learning dapat meningkatkan kemampuan kognitif siswa dalam proses pembelajaran fisika di abad 21. Media hologram 3D merupakan salah satu inovasi terbaru yang dikembangkan dalam dunia pendidikan. Media ini menjadi salah satu alternatif bagi siswa untuk lebih tertarik lagi dalam proses kegiatan belajar berlangsung di dalam kelas, karena media hologram 3D merupakan perpaduan dua cahaya koheren yang di dalamnya membentuk objek-objek tiga dimensi. Kompleksitas teknologi di abad 21 meringankan kemampuan siswa untuk memahami dan mengerti dalam proses pembelajaran. Hal ini disebabkan karena lingkungan komputansi dan pengembangan aplikasi merupakan alat pengajaran efektif yang mampu meningkatkan kemampuan kognitif anak.

\section{METODE PENELITIAN}

Metode yang digunakan dalam penelitan ini yaitu studi kepustakaan. Data dikumpulkan dengan mengkaji beberapa literatur untuk dianalisis kemudian disajikan 
dalam hasil dan pembahasan agar dapat dibuat kesimpulan.

\section{HASIL DAN PEMBAHASAN}

\section{A. Blended Learning}

Istilah "blended learning" dapat diartikan menjadi beberapa makna. Secara umum, blended learning mengacu pada perpaduan lingkungan belajar yang berbeda. Perpaduan ini bisa menggabungkan proses pembelajaran asynchronous dan synchronous, face to face dan distance learning (Nana \& Surahman, 2019: 87). Blended learning merupakan salah satu model pembelajaran yang efektif untuk digunakan dalam proses pembelajaran fisika di abad 21. Hal itu terjadi karena pada abad 21 terjadi pekembangan teknologi yang sangan pesat sehingga dunia pendidikan dibutuhkan model pembelajran untuk menyesuaikan perkembangan di abad 21.

Tujuan dari model pembelajaran blended learning yaitu untuk memadukan pembelajaran tatap muka langsung dengan guru dan pembelajaran berbasis online sehingga proses pembelajaran dapat berjalan secara efektif.

B. Hologram 3D

Holografi adalah sebuah proses perekaman cahaya dari suatu benda yang kemudian direkontruksi sehingga objek seolah-olah berada pada posisi yang relatif sama dengan media rekaman yang direkam. Gambar berubah sesuai dengan posisi dan orientasi dari perubahan sistem pandangan dalam cara yang sama seperti saat objek itu masih ada, sehingga gambar yang direkam akan muncul secara tiga dimensi (3D) yang biasa disebut dengan hologram (Jaya \& Lu'mu, 2010: 784). Salah satu produk dari hografi adalah hologram. Hologram merupakan perpaduan dua sinar cahaya yang koheren dan dalam bentuk mikroskopik yang didalamnya memuat objek-objek 3 dimensi (3D).

C. Kemampuan Kognitif

Menurut Sanjaya (2011), kemampuan atau kompetensi merupakan perilaku rasional untuk mencapai tujuan yang dipersyaratkan sesuai dengan kondisi yang diharapkan. Kognitif adalah suatu proses berpikir yaitu kemampuan individu untuk menghubungkan, menilai, dan mempertimbangkan suatu kejadian atau peristiwa (Susanto, 2011: 48). Jadi kemampuan kognitif adalah kemampuan yang berkembang pada individu untuk berpikir, belajar, dan memecahkan masalah. Perkembangan kognitif anak meliputi perubahan mental, perilaku, keterampilan, pemikiran persepsi, dan pengolahan sistem informasi yang memunginkan seseorang memperoleh pengetahuan untuk memecahkan suatu masalah.

D. Penerapan Model Blended Learning dengan Media Hologram 3D Sebagai Inovasi Pembelajaran Fisika Untuk 
Meningkatkan Kemampuan Kognitif Siswa SMA di Abad 21

Salah satu masalah di abad 21 dalam dunia pendidikan yaitu bagaimana meningkatkan kemampuan kognitif siswa sesuai dengan perkembangan teknologi. Setiap siswa dituntut untuk memiliki kemampuan berpikir dan intelektual tinggi dalam proses pembelajaran. Dengan demikian seorang guru harus membuat model pembelajaran yang sesuai dengan perkembangan teknologi dan kemampuan siswa. Salah satu model pembelajaran yang sesuai yaitu model blended learning. Blended learning merupakan salah satu pemecahan masalah sesuai dengan kemajuan teknologi di abad 21. Model blended learneng ini mencampurkan media pembelajaran tatap muka langsung dengan teknologi (e-learning). Teknologi (e-learning) yang digunakan yaitu dengan media hologram 3D yang bertujuan untuk memudahkan pemahaman siswa dalam pembelajaran fisika SMA. Menurut Jauhar (Nana, 2014) menyatakan bahwa standar kompetensi untuk bidang sains pada jenjang SMA ditekankan pada kemampuan bekerja ilmiah, dan kemampuan memahami konsep-konsep sains serta penerapannya dalam kehidupan. Oleh karena itu media hologram 3D pantas untuk diterapkan dalam pembelajaran fisika SMA. Sebagai contoh penerapan media hologram 3D pada pembelajaran fisika yaitu dengan memungkinkan siswa SMA untuk diajar oleh "guru virtual" yang bisa mencapai ribuan kilometer jauhnya. guru hologram tampak ada di dalam kelas, dan dapat melihat dan berbicara dengan murid-murid seolah-olah mereka semua di ruangan yang sama karena tampilan guru virtual dalam hologram berbentuk tiga dimensi. Selain itu dapat digunakan dalam materi getaran dan gelombang yang membutuhkan gamabaran secara jelas mengenai materi tersebut sehingga dibutuhkan media hologram 3D karena dapat menampikan gambar secara tiga dimensi.

Pada dasarnya, penerapan model pembelajaran harus disesuaikan dengan kebutuhan dan tujuan yang dicapai oleh guru. Dengan adanya inovasi pembelajaran menggunkaan media hologram 3D dapat meningkatkan kemampuan kognitif anak dalam pembelajaran fisika di bidang teknologi. Inovasi pembelajaran sebagai perubahan yang baru dalam meningkatkan kemampuan demi mencapai tujuan tertentu berupa praktik-praktik pendidikan (Nana, 2018: 193). Oleh sebab itu, penerapan media hologram 3D dalam model blended learning sebagai salah satu upaya untuk meningkatan kemampuan berpikir dan intelektual siswa SMA. 


\section{KESIMPULAN}

Penerapan model blended learning dalam pembelajaran fisika dapat meningkatkan kemampuan kognitif siswa. Sejalan dengan perkembangan teknologi di abad 21, siswa harus menyesuaikan diri dengan dengan perkembangan teknologi dalam bidang pendidikan yaitu dengan menggunakan media hologram 3D dalam proses pembelajaran fisika SMA.

\section{UCAPAN TERIMA KASIH}

Terima kasih kepada semua pihak yang telah membantu demi kesempurnaan artikel ini menjadi lebih baik diantaranya:

1. Kepada Bapak Dr. Nana, M.Pd. selaku dosen mata kuliah Fisika Seklah II;

2. Kepada teman-teman yang telah membantu.

\section{DAFTAR PUSTAKA}

Akhmalia, N, L., Maharta, N., \& Suana, W. (2018). Efektivitas Blended Learning Berbasis LMS dengan Model Pembelajaran Inkuiri pada Materi Fluida Statis terhadap Penguasaan Konsep Siswa. Jurnal Inovasi Pendidikan Fisika dan Riset Ilmiah, 2(2), $56-64$.

Jaya, H., \& Lu'mu. (2010). Teknologi Holografi Untuk Pembelajaran Virtual Pada Sekolah Menengah Kejuruan. Jurnal Elektronika Telekomunikasi dan Computer, 5(1), 783-791.
Nana \& Endang Surahman. (2019). Pengembangan Inovasi Pembelajaran Digital Menggunakan Model Blended POE2WE di Era Revolusi Industri 4.0. Prosiding Seminar Nasional Fisika dan Aplikasinya, pp. 82-90.

Nana, Sajidan, Akhyar, M., \& Rochsantiningsih, D. (2014). Pengembangan Pembelajaran Fisika SMA Melalui Elaboration Write and Evaluation (EWE) dalam Kurikulum 2013. Seminar Nasional Pendidikan Sains, [Online]. Tersedia: https://jurnal.fkip.uns.ac.id/index.ph $\mathrm{p} / \mathrm{snps} /$ article/view/4944.

Nana. (2018). Penerapan Model Creative Problem Solving Berbasis Blog Sebagai Inovasi Pembelajaran di Sekolah Menengah Atas dalam Pembelajaran Fisika. Prosiding Seminar Nasional Fisika dan Aplikasinya, pp. 190-195.

Pramuda, A., \& Angraeni, L.. (2016). Pengembangan Media Pembelajaran Getaran Dan Gelombang Berbasis Holografi. Jurnal Pendidikan Informatika dan Sains, 5 (2): 157173.

Rovai, A. P., \& Jordan, H. (2004). Blended learning and sense of community: A comparative analysis with traditional and fully online graduate courses. The International Review of Research in Open and Distributed Learning, 5(2), 1-13. http://dx.doi.org/10.19173/irrodl.v5i 2.192

Sanjaya, Wina. (2011). Strategi Pembelajaran Berorientasi Standar Proses Pendidikan. Jakarta: Kencana. 